\title{
Impact of Heuristic Strategy on Students' Mathematics Ability in High Order Thinking
}

\author{
Hardi Tambunan ${ }^{1 *}$ \\ ${ }^{1}$ Department of Mathematics Education, Nommensen HKBP University, Medan, INDONESIA \\ * CORRESPONDENCE: $\$ tambunhardi@gmail.com
}

\begin{abstract}
The purpose of this study is to determine the impact of heuristic strategy on students' mathematical abilities in high order thinking. This descriptive research uses a correlation design. The population of this study were all second-grade public and private high school students representing schools from eight districts in North Sumatra province, and samples $(N=257)$ were taken randomly. Based on linear regression analysis through analysis of variance (ANOVA) results obtained that heuristic strategy has a very strong influence on students 'mathematical abilities in high order thinking, and partially heuristic strategies affect students' ability in (1) understanding of concepts, (2) creativity, (3) mathematical communication, (4) problem solving, and (5) reasoning ability.
\end{abstract}

Keywords: heuristic strategy, students' mathematical abilities, HOT

\section{INTRODUCTION}

The ability of students is one of the main factors in mathematics education, because it can be used to determine the success of the implementation and success of students absorbing learning material. Currently education in Indonesia, is using the 2013 curriculum with the target of students having mathematical abilities with high order thinking (HOT) in accordance with PISA standards. However, the expected results have not been achieved well, where the average national mathematics test scores decreased from the previous year (Effendy, 2018). The importance is HOT in learning mathematics so students can master mathematics well (Amalia, 2013). The results showed that there was a significant relationship between HOT and student learning outcomes (Jailani, 2017; Tanujaya, 2017; Widodo \& Kadarwati, 2013).

Some of the main factors that influence HOT students in mathematics are seen from external factors such as unfavorable learning processes (Al-Agili, 2012; Heleni, 2009), teachers are not good at choosing learning strategies (Margaret, 2015), the problem is not in accordance with the ability of students (Tambunan, 2016, 2018), the teacher does not carry out his role as a motivator (Tambunan, 2018), and can increase HOT students (Kurniati, 2016; Prasetyani, 2016; Saragih \& Napitupulu, 2015; Ulfa, 2013). Therefore, the learning approach becomes an important factor in mathematics learning so that students have HOT abilities. Many strategies have been developed by education experts to be used in mathematics learning, one of which is the heuristic strategy. This research question is how is the impact of heuristic strategy on students' mathematical abilities in high order thinking? The purpose of this study is to determine the effect of heuristic strategy on students' mathematical abilities in high order thinking.

\footnotetext{
Article History: Received 8 May $2018 \bullet$ Revised 9 September $2018 \bullet$ Accepted 3 October 2018

(C) 2018 The Author(s). Open Access terms of the Creative Commons Attribution 4.0 International License (http://creativecommons.org/licenses/by/4.0/) apply. The license permits unrestricted use, distribution, and reproduction in any medium, on the condition that users give exact credit to the original author(s) and the source, provide a link to the Creative Commons license, and indicate if they made any changes.
} 


\section{HEURISTIC STRATEGY}

Strategy is an effort activity, design, approach, and a series of steps taken by the teacher to achieve an educational goal (Hamdani, 2011; Hamzah \& Muhlisrarini, 2014; Ngalimun, 2014; Riyanto, 2010; Yamin, 2013). The implementation of learning strategies can be given some important heuristics to make it easier for students to understand the subject matter. Heuristics as an adjective, means "serving to discover" (Polya, 1973). Heurists help to find solutions (Webster's, 1985). Heuristics are general suggestions that help an individual to make progress toward its solution (Shoenfeld, 1985). Heuristics is a guide that can lead to problem solvers to find a solution to the problem (Tambunan, 2014).

Studying mathematics means learning to solve problems, both problems related to everyday problems as well as solving mathematical problems themselves. Problems in mathematics are questions in mathematics to be solved (Baroody, 1993; James, 1976). Polya (1973) states four stages in problem solving learning, namely (1) understanding the problem, (2) planning a solution, (3) completing the model, and (4) checking again. A strategy by giving a heuristic in the form of statements, commands or questions to all four stages and problem solving steps is called a heuristic strategy (Tambunan, 1999).

The heuristic strategy in learning mathematics using these four stages can be summarized as follows. The first stage is understanding the problem. At this stage, giving heuristic aims to direct students to understanding concepts so that they can communicate phenomena that exist in various forms and in the language of mathematics, and students can have good creativity. The second stage is planning a solution. At this stage heuristic is aimed at directing students to be able to make completion plans by giving several heuristics so that students can be creative to communicate the elements and traits that exist so that a settlement plan or mathematical model can be used to solve existing problems.

The third stage is carrying out the completion plan. Heuristics are given to direct students to find conclusions, traits or solve existing problems, so that students have the ability to find and solve existing problems. The fourth stage is checking again. The provision of heuristics aims to direct students to check the correctness of the steps taken and the results obtained. The implementation of the heuristic strategy will have an impact on students' reasoning abilities.

\section{HIGH ORDER THINKING IN MATHEMATICS}

Measuring mathematical abilities used several items in accordance with the targeted test material. Indicator of mathematical ability that refers to HOT, namely the ability to understand concepts, mathematical communication (Madu, 2017), creativity, problem solving (Setiawan, 2014; Wardhani, 2015), and reasoning (Brookhart, 2010). Concept understanding can be interpreted as a basic understanding ability that can be used to classify an object. Understanding concepts is the ability of students to restate what has been learned (Duffin \& Simpson, 2000). Operational indicators to measure the ability to understand concepts, namely (1) explain the concept in various ways, (2) classify according to its properties, (3) explain the requirements needed for an understanding, (4) show an example form of a concept, (5) show form is not an example of a concept, (6) use concepts for problem solving, (7) use concepts for problem solving.

Communication is an important part in every learning activity. Mathematics is a symbolic language that can be used in science. Mathematics is a language that can be used in communication (Armianti, 2009). Studying mathematics means having mathematical communication skills (Dan, 2013). The benefits of mathematical communication in learning mathematics are as a capital for mathematical completion (Greenes \& Schulman, 1996), and as an important condition for communicating various ideas into the language of mathematics (Baroody, 1993). Operational indicators for measuring mathematical communication skills, namely (1) reflecting things into the language of mathematics, (2) explaining the typing through mathematical symbols (3) explaining mathematical problems or problems through the language of mathematics, (4) explains how to make a story based on a picture or mathematical model, (5) describes how to translate everyday problems into mathematical language.

Creativity is one's ability to produce new things. Munandar (2012) states that creativity is the ability to create something new. Creativity is a cognitive activity that produces a new way of looking at a problem (Solso, 1995). Creativity in mathematics is defined as the ability to see and choose a solution in mathematics (Sriraman, 2011). Some aspects of mathematical creativity, namely flexibility, fluency, novelty, sensitivity, originality, and elaboration (Evans, 1991; Silver, 1997). Operational indicators to measure the ability of mathematical creativity, namely (1) explain some examples of solving mathematical problems until all 
students understand, (2) explain some understanding of an image, pattern, diagram, or mathematical problem, (3) explain in several ways to solve math problems, (4) explain in several ways to find alternative answers from a problem or mathematical problem, (5) develop an idea or idea to solve a mathematical problem.

Learning mathematics means learning a problem, namely a question in mathematics to be solved (Baroody, 1993; James, 1976; Tambunan, 2014), and a question becomes a matter problems if there are no certain rules can be used to solve them (Hudoyo, 2005). Operational indicators to measure problem solving abilities, namely (1) explain what is known and asked in story problems, (2) explain the adequacy of the elements known to answer the questions asked in the story, (3) explain how to make a mathematical model of a story problems or mathematical problems, (4) solving mathematical models systematically. Reasoning is a process of thinking in drawing conclusions based on inductive and deductive (Sumantri, 2009). Operational indicators for measuring mathematical reasoning ability, namely (1) stating definitions, propositions, theorems, problems or problems with their own language orally or in writing, (2) presenting statements, problems or mathematical problems through sketching pictures, patterns, tables or diagrams, (3) translating a daily problem into the language of mathematics, (4) directly proving a statement (formula, proposition or theorem) of mathematics, (5) checking the truth a mathematical problem solving, (6) drawing conclusions from a mathematical statement or solving a mathematical problem, (7) arranging the form, pattern or properties of mathematics to make general conclusions.

\section{METHOD}

This descriptive research uses a correlation design. The population of this study were all students of the second grade of state and private high schools, the 2018-2019 academic year represented by eight schools and districts in the province of North Sumatra, and from each school randomly sampled 257 students $(\mathrm{N}=257)$.

Data collection techniques were carried out by giving questionnaires and tests to students. The questionnaire contains questions about students' responses to the implementation of heuristic strategy (X) with the syntax of understanding of the concept (X1), creativity (X2), mathematical communication (X3), problem solving (X4), and reasoning (X5). Test consists of several items that include the ability to HOT (Y) with indicators of understanding of the concept (Y1), creativity (Y2), mathematical communication (Y3), problem solving (Y4), and reasoning (Y5) in the linear program material. Data analysis used linear regression through covariance analysis (Mann, 2011).

\section{RESULT}

Based on the results of linear regression analysis through analysis of variance (ANOVA) with SPSS version 19 , the following results were obtained. The influence of heuristic strategy on students' mathematical abilities with high order thinking is generally described in the results of linear regression analysis in the following table.

Table 1. Model Summary of Predictors X and Dependent Variable Y

\begin{tabular}{ccccc}
\hline Model & $\mathbf{R}$ & R Square & Adjusted R Square & Std. Error of the Estimate \\
\hline 1 & .869 & .755 & .754 & 7.28981 \\
\hline a. Predictors: (Constant), X & & &
\end{tabular}

Table 2. ANOVA

\begin{tabular}{clccccc}
\hline & Model & Sum of Squares & df & Mean Square & F & Sig. \\
\hline \multirow{3}{*}{1} & Regression & 41703.066 & 1 & 41703.066 & 784.757 & .001 \\
\cline { 2 - 7 } & Residual & 13551.051 & 255 & 53.141 & & \\
\cline { 2 - 7 } & Total & 55254.117 & 256 & & & \\
\hline \multirow{2}{*}{ a. Predicton }
\end{tabular}

a. Predictors: (Constant), $\mathrm{X}$

b. Dependent Variable: Y

The analysis results in Table 1 and Table 2 show that the predictor x greatly influences the independent variable Y. That means that the heuristic strategy is very influential on the mathematical ability of students with HOT whose influence is $75.5 \%$. The results of the analysis simultaneously heuristic strategy on mathematical abilities are described as the following table. 
$\underline{\text { Table 3. Model Summary }}$

\begin{tabular}{ccccc}
\hline \multicolumn{5}{c}{ Table 3. Model Summary } \\
\hline Model & $\mathrm{R}$ & R Square & Adjusted R Square & Std. Error of the Estimate \\
\hline 1 & .895 & .801 & .797 & 6.61728 \\
\hline
\end{tabular}

a. Predictors: (Constant), X1, X2, X3, X4, X5

Table 4. ANOVA

\begin{tabular}{llccccc}
\hline & Model & Sum of Squares & df & Mean Square & F & Sig. \\
\hline \multirow{3}{*}{1} & Regression & 44263.222 & 5 & 8852.644 & 202.169 & .001 \\
\cline { 2 - 7 } & Residual & 10990.895 & 251 & 43.788 & & \\
\cline { 2 - 8 } & Total & 55254.117 & 256 & & & \\
\hline
\end{tabular}

a. Predictors: (Constant), X1, X2, X3, X4, X5

b. Dependent Variable:Y

Based on Table 3 and Table 4 it is shown that simultaneously heuristic strategies affect students' mathematical abilities, and the effect is $80.1 \%$

Furthermore, the results of partial linear regression analysis heuristic strategy for mathematical abilities are described as in Table $\mathbf{5}$.

Table 5. Summary of partial regression analysis heuristic strategy for mathematical abilities

\begin{tabular}{|c|c|c|c|c|c|c|c|c|c|c|}
\hline Var. & & Y1 & & Y2 & & Y3 & & Y4 & & Y5 \\
\hline & $\mathbf{R}^{2}$ & $\mathbf{F}$ & $\mathbf{R}^{2}$ & $\mathbf{F}$ & $\mathbf{R}^{2}$ & $\mathbf{F}$ & $\mathbf{R}^{2}$ & $\mathbf{F}$ & $\mathbf{R}^{2}$ & $\mathbf{F}$ \\
\hline $\mathrm{X} 1$ & 0.614 & $408.799^{* * *}$ & & & & & & & & \\
\hline $\mathrm{X} 2$ & & & 0.480 & $235.174^{* *}$ & & & & & & \\
\hline X3 & & & & & 0.625 & $425.089^{* *}$ & & & & \\
\hline $\mathrm{X} 4$ & & & & & & & 0.513 & $269.124^{* *}$ & & \\
\hline X5 & & & & & & & & & 0.622 & $419.722^{* *}$ \\
\hline
\end{tabular}

Based on the summary of partial regression analysis in Table $\mathbf{5}$ shows that significantly heuristic strategy affect on each indicator of mathematical ability with high order thinking. The influence of heuristic strategy on concept understanding, creativity, mathematical communication, problem solving, and reasoning were $61.8 \%, 48.0 \%, 62.5 \%, 51.3 \%$, and $62.2 \%$ respectively.

\section{DISCUSSION}

The results of this study indicate that heuristic strategy greatly influence the mathematical ability of students in thinking high orders. This is consistent with the results of research that shows that learning strategies can improve students' abilities (Fauziah, 2010), and the heuristic approach is better than conventional towards student achievement (Abonyi, 2014). Partially heuristic strategy affect the mathematical ability of students in high order thinking (HOT). The effect of heuristic strategy on concept comprehension ability is $61.8 \%$. This is consistent with the results of the study that learning using learning strategies can affect the ability to understand concepts (Alifiani, 2017; Hadi \& Kasum, 2015; Sari, 2017; Sumaryati \& Hasanah, 2015).

The effect of heuristic strategy on creativity ability is $48.0 \%$. This is consistent with the results of the study that learning strategies can improve mathematical creative thinking skills (Nanang, 2016; Sormin, 2016; Rahmazatullaili, 2017; Rochani, 2016). The effect of heuristic strategy on mathematical communication ability is $62.5 \%$. This consistent with the result of the study that learning with a strategy can improve students' mathematical communication (Anggreni \& Sumarno, 2013; Fatmasuci, 2017; Habsah, 2017; Hodiyanto, 2017; Kleden, 2017).

The effect of heuristic strategy on problem solving ability is 51.3\%. The results are in accordance with Chavez's (2007) statement that heuristics are effectively used in problem solving. Heuristics provide positive results on problem solving abilities (Hoona, 2013; Novotna, 2014). The influence of heuristic strategy on reasoning ability is $62.2 \%$. This consistent with the result of the study that learning with strategies is better than a conventional approach to reasoning ability (Ario, 2016; Satriawan, 2017; Sumartini, 2015; Wibowo, 2017; Yumiati \& Noviyanti, 2017). 


\section{CONCLUSION}

Heuristic strategy is a learning approach by giving heuristics to problem solving steps. The implementation of mathematics learning, the use of heuristic strategies can be used to direct students to conceptual understanding, creativity, mathematical communication, problem solving and reasoning, so that students have high order thinking skills (HOTS). Based on the results of this study it can be stated that heuristic strategies have a strong influence on students' mathematical abilities in high order thinking (HOT).

Partially heuristic strategy influences students' abilities in each HOT indicator, namely the ability of concept understanding, creativity, mathematical communication, problem solving and reasoning ability.

\section{Disclosure statement}

No potential conflict of interest was reported by the authors.

\section{Notes on contributors}

Hardi Tambunan - Nommensen HKBP University, Medan, Indonesia.

\section{REFERENCES}

Abonyi, O. S., \& Umeh, V. O. (2014). Effects of Heuristic Method of Teaching on Students' Achievement in Algebra. International Journal of Scientific \& Engineering Research, 5(2), 1735-1740. Retrieved from http://citeseerx.ist.psu.edu/viewdoc/download?doi=10.1.1.429.2101\&rep=rep1\&type=pdf

Al-Agili M. Z. G, et al. (2012). The Factors Influence Students' Achievement in Mathematics: A Case for Libyan's Students. World Applied Sciences Journal, 17(9), 1224-1230. Retrieved from https://pdfs.semanticscholar.org/a8ab/ 0e09da8190624db89ac91df1237912fdb8b9.pdf

Alifiani. (2017). Penerapan Model Pembelajaran NHT-TGT untuk Meningkatkan Motivasi dan Pemahaman Konsep Materi Matematika SMA. Jurnal Riset Pendidikan Matematika, 4(1), 11-20. https://doi.org/10.21831/jrpm.v411.13100

Amalia, R. (2013). Penerapan Model Pembelajaran Pembuktian Untuk Meningkatkan Kemampuan Berpikir Matematis Tingkat Tinggi Siswa SMA. Universitas Pendidikan Indonesia, 2013. Retrieved from http:// repository.upi.edu/1844/1/TMTK1 104452_TITLE.pdf

Anggraeni, D., \& Sumarno, U. (2013). Meningkatkan Kemampuan Pemahaman dan Komunikasi Matematika Siswa SMK Melalui Pendekatan Kontekstual dan Strategy Formulate-Share-Listen-Create (FSLC). Infinity, Jurnal Ilmiah Program Studi Matematika STKIP Siliwangi Bandung, 2(1), 1-12

Ario, M. (2016). Analisis Kemampuan Penalaran Matematis Siswa SMK Setelah Mengikuti Pembelajaran Berbasis Masalah. Jurnal Ilmiah Edu Research, 5(2), 125-134

Armianti. (2009). Komunikasi Matematika dan Kecerdasan Emosional. Prosiding Seminar Nasional Matematika dan Pendidikan Matematika Jurusan Pendidikan Matematika FMIPA UNY, 5, 270-280. Retrieved from http://eprints.uny.ac.id/7030/1/P16-Armiati.pdf

Baroody, A. J. (1993). Problem Solving. Reasoning, and Communicating K-8 (Helping Children Think Mathematically). New York: Macmillan Publishing Company.

Brookhart, S. M. (2010). How to Assess Higher-Order Thinking Skills in Your Classroom. Alexandria: ASCD

Chavez, J. A. (2007). Enlivening Problems with Heuristics through Learning Activities and Problem Solving (LAPS). Learning Science and Mathematics, SEAMEO RECSAM, (2), 1-8. Retrieved from http://ftp.recsam.edu.my/lsm/2007/2007_1_JAC.pdf

Dan, S. (2013). The Study on Mathematical Communication Competence and Its Assessment in China: The Preliminary Findings. East Normal University. Proceedings Ear come 6. Innovations and Exemplary Practices in Mathematics Education, 17-22

Duffin, J. M., \& Simpson, A. P. (2000). A Search for Understanding. Journal of Mathematical Behavior, 18(4), 415-427. https://doi.org/10.1016/S0732-3123(00)00028-6

Effendy, M. (2018). Soal Ujian Nasional Sulit. Mendikbud. Retrieved from http://www.google.co.id

Evans, J. R. (1991). Creative Thinking in the Decision and Management Scince. USA: South-Western Publishing Co. 
Fatmasuci, F. W. (2017). Pengembangan Perangkat Pembelajaran Berbasis Masalah Berorientasi Pada Kemampuan Komunikasi dan Prestasi Belajar Matematika Siswa SMP. Jurnal Riset Pendidikan Matematika, 4(1), 32-42. https://doi.org/10.21831/jrpm.v4i1.11325

Fauziah, A. (2010). Peningkatan Kemampuan Pemahaman dan Pemecahan Masalah Matematika Siswa SMP Melalui Strategi REACT. Forum Kependidikan, 20(1), 1-13.

Greenes, C., \& Schulman, L. (1996). Communication Process in Mathematical Exploration and Investigation. In P.C Elliot and M.J Kenney (Ed). Communication in Mathematics, K-12 and Beyond. USA: NCTM

Habsah, F. (2017). Developing Teaching Material Based on Rrealistic Mathematics Andoriented to the Mathematical Reasoning and Mathematical Ccommunication. Jurnal Riset Pendidikan Matematika, 4(1), 43-55. https://doi.org/10.21831/jrpm.v4i1.10199

Hadi, S., \& Kasum, M. U. (2015). Pemahaman Konsep Matematika Siswa SMP Melalui Penerapan Model Pembelajaran Kooperatif Tipe Memeriksa Berpasangan (Pair Cheks). EDU-MATJurnal Pendidikan Matematika, 3(1), 59-66.

Hamdani. (2011). Strategi Belajar Mengajar. Bandung: Pustaka Setia

Hamzah, H. M., \& Muhlisrarini. (2014).Perencanaan dan Strategi Pembelajaran Matematika. Jakarta: PT Rajagrapindo Persada

Heleni S. (2009). Pembelajaran Kooperatif tipe STAD yang Diawali dengan Pemberian Soal Cerita untuk Meningkatkan Hasil Belajar Matematika Siswa Kelas VII SMPN 13 Pekanbaru. Prosiding Seminar Serantau ke 4. Retrieved from https://docmh.net/the-philosophy-of-money.html?utm_source=atur-caraseminar-pendidikan-serantau

Hodiyanto. (2017). Kemampuan Komunikasi Matematis dalam Pembelajaran Matematika. AdMathEdu, 7(1), 9-17.

Hoona, T. H., Kee, K. L., \& Singh, P. (2013). Learning Mathematics Using Heuristic Approach. Procedia Social and Behavioral Sciences, 90, 862-869. Retrieved from https://core.ac.uk/download/pdf/82785844.pdf https://doi.org/10.1016/j.sbspro.2013.07.162

Hudoyo, H. (2005). Pengembangan Kurikulum Matematika dan Pelaksanaannya di Depan Kelas. Surabaya: Usaha Nasional.

Jailani, J., Sugiman, S., \& Apino, E. (2017). Implementing the Problem-Based Learning in Order to Improve the Students' HOTS and Characters. Jurnal Riset Pendidikan Matematika, 4(2), 247-259. https://doi.org/10.21831/jrpm.v4i2.17674

James. G., James, R. C., \& Alchian, A. A. (1976). Mathematics Dictionary. New York: Van Nostrand Reinhold Co

Kleden, M. A., Geradus, U., \& Sugi, Y. (2017). Meningkatkan Kemampuan Komunikasi Matematis Siswa SMP Melalui Pembelajaran Kontekstual Berbasis Budaya Pesisir. Seminar Nasional Matematika dan Aplikasinya. Surabaya, Universitas Airlangga. 150-159. Retrieved from http://math.fst.unair.ac.id/wpcontent/uploads/ 2017/10/23-Maria-A.-Kleden_Undana_Pendidikan_.pdf

Kurniati, D., Harimukti, R., \& Jamil, N. A. (2016). Kemampuan Berpikir Tingkat Tinggi Siswa SMP di Kabupaten Jember dalam Menyelesaikan Soal Berstandar PISA. Jurnal Penelitian dan Evaluasi Pendidikan, 20(2), 142-155. Retrieved from http://journal.uny.ac.id/index.php/jpep https://doi.org/10.21831/pep.v20i2.8058

Madu, A. (2017). Higher Order Tingking Skills (Hots) In Math Learning. IOSR Journal of Mathematics (IOSR$J M), 13(5)$, 70-75. Retrieved from http://www.iosrjournals.org/iosr-jm/papers/Vol13-issue5/Version-2/ L1305027075.pdf

Mann, P. S. (2011). Introductory Statistics. USA: Estern Connecticut State University.

Margaret, P. (2015). The Cause of the Low Mathematics Score in Indonesia. Retrieved from http://news.okezone.com/read/ 2014/09/09/3v3/1036506/ini-penyebab-nilai-matematika-indonesiarendah

Munandar, U. (2012). Pengembangan Kreativitas Anak Berbakat. Jakarta: Rineka Cipta.

Nanang, A. (2016). Berpikir Kreatif Matematis dan Kemandirian Belajar dalam Pembelajaran Berbasis Masalah. Mimbar Sekolah Dasar, 3(2), 171-182. https://oi.org/10.17509/mimbar-sd.v3i2.4283

Ngalimun. (2014). Strategi dan Model Pembelajaran. Yogyakarta: Aswaja Presindo. 
Novotná, J., et al. (2014). Problem Solving in School Mathematics Based on Heuristic Strategies. Journal on Efficiency and Responsibility in Education and Science, 7(1), 1-6. https://doi.org/10.7160/ eriesj.2013.070101

Polya, G. (1973). How to Solve It. New Jersey. Princeton

Prasetyani, E., Hartono, Y., \& Susanti E. (2016). Kemampuan Berpikir Tingkat Tinggi Kelas XI Dalam Pembelajaran Trigonometri Berbasis Masalah di SMA Negeri 18 Palembang. Jurnal Gantang, 1(1), 3140. https://doi.org/10.31629/jg.v1i1.4

Rahmazatullaili., Zubainur, C. M., \& Munzir, S. (2017). Kemampuan Berpikir Kreatif dan Pemecahan

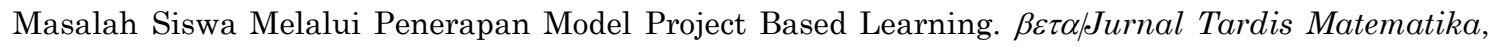
10(2), 166-183. https://doi.org/10.20414/betajtm.v10i2.104

Riyanto, H. Y. (2010). Paradigma Baru Pembelajaran. Jakarta: Kencana Prenada Media Group.

Rochani, S. (2016). Keefektifan Pembelajaran Matematika Berbasis Masalah dan Penemuan Terbimbing Ditinjau Dari Hasil Belajar Kognitif Kemampuan Berpikir Kreatif. Jurnal Riset Pendidikan Matematika, 3(2), 273-283. https://doi.org/10.21831/jrpm.v3i2.5722

Saragih, S., \& Napitupulu, E. (2015). Developing Student-Centered Learning Model to Improve High Order Mathematical Thinking Ability. International Education Studies, 8(6), 41-52. https://doi.org/10.5539/ies.v8n6p104

Sari, E. F. P. (2017). Pengaruh Kemampuan Pemahaman Konsep Matematika Mahasiswa Melalui Metode Pembelajaran Learning Strats with A Question. Jurnal “Mosharafa”, 6(1), 25-34. Retrieved from http://e-mosharafa.org /index.php/mosharafa

Satriawan, R. (2017). Keefektifan Model Search, Solve, Create, and Share Ditinjau dari Prestasi, Penalaran Matematis, dan Motivasi Belajar. Jurnal Riset Pendidikan Matematika, 4(1), 87-99. https://doi.org/10.21831/jrpm.v4i1.7863

Schoenfeld, A. H. (1985). Mathematical Problem Solving. USA. Academic Press, Inc.

Setiawan, H. (2014). Soal Matematika Dalam PISA Kaitannya Dengan Literasi Matematika dan Keterampilan Berpikir Tingkat Tinggi. Prosiding Seminar Nasional Matematika, Universitas Jember. Retrieved from https://jurnal. unej.ac.id/index.php/psmp/article/download/955/758

Silver, E. A. (1997). Fostering Creativity through Instruction Rich in Mathematical Problem Solving and Thinking in Problem Posing. ZDM, 29(3), 45-62. Retrieved from http://www.fiz.karlsruhe.de/fiz /publications/zdm

Solso, R. L. (1995). Cognitive Psychology. Needham Heights, MA: Allyn \& Bacon.

Sormin, M. A. (2016). Upaya Meningkatkan Kreativitas Belajar Matematika Siswa Melalui Pembelajaran Cooperative Learning Tipe Jigsaw di SMK Negeri Padangsidempuan. Jurnal Eksakta, 2(1), 19-27.

Sriraman, B. (2011). The Elements of Creativity and Giftedness in Mathematics. Rotterdam: Sense Publishers. https://doi.org/10.1007/978-94-6091-439-3

Sumantri, J. S. (2009). Filsafat Ilmu, Jakarta Pustaka Sinar Harapan

Sumartini, T. S. (2015). Peningkatan Kemampuan Penalaran Matematis Siswa Melalui Pembelajaran Berbasis Masalah. Jurnal Pendidikan Matematika, 5(1), 1-10.

Sumaryati, A. S., \& Hasanah, D. U. (2015). Upaya Meningkatkan Pemahaman Konsep Matematika dengan Model Pembelajaran Inkuiri Terbimbing Siswa Kelas VIII C SMP Negeri 11 Yogyakarta. Jurnal Derivat, 2(2), 56-64.

Tambunan, H. (1999). Kemampuan Siswa Menyelesaikan Soal Cerita Pokok Bahasan Trigonometri dengan Strategi Heuristik. (Unpublished Master Tesis), IKIP Surabaya.

Tambunan, H. (2014). Strategi Heuristik dalam Pemecahan Matematika Sekolah. Jurnal Saintech, 6(4), 3540.

Tambunan, H. (2016). Mathematical Model for Mapping Students' Cognitive Capability. International Journal of Evaluation and Research in Education (IJERE), 5(3), 221-226. https://doi.org/10.11591/ijere.v5i3.4543

Tambunan, H. (2018). The Dominant Factor of Teacher's Role as A Motivator of Students' Interest and Motivation in Mathematics Achievement. International Education Studies, 4(4), 144-151. https://doi.org/10.5539/ies.v11n4p144 
Tambunan, H., \& Mawengkang, H. (2018). Integer Linear Programming Approach for Detection Learning Outcomes Achievement. Far East Journal of Mathematical Sciences (FJMS), 105(1), 95-109. https://doi.org/10.17654/MS105010095

Tanujaya, B., Mumu, J., \& Margono, G. (2017). The Relationship between Higher Order Thinking Skills and Academic Performance of Student in Mathematics Instruction. International Education Studies, 10(11), 78-84. URL: https://doi.org/10.5539/ies.v10n11p78

Ulfa, W., et al. (2013). Pengaruh Strategi Pembelajaran Berbasis Masalah Terhadap Kemampuan Berpikir Tingkat Tinggi (Menganalisis,Mengevaluasi, Mencipta) dan Keterampilan Proses Sains Mahasiswa STIPAP LPP Medan, Jurnal UNIMED: 1-5.

Wardhani, S. (2015). Pembelajaran dan Penilaian Aspek Pemahaman Konsep, Penalaran dan Komunikasi, Pemecahan Masalah. Retrieved from http://p4tkmatematika.org/file/PRODUK/PAKETFASI LITASI/ SMP/Standar Penilaian Pendidikan.pdf

Webster's. (1983). Webster's New Twenttieth Century Dictionary of English Laguage. USA, William Collins Publisher, Inc.

Wibowo, A. (2017). Pengaruh Pendekatan Pembelajaran Matematika realistic dan Saintific Terhadap Prestasi Belajar, Kemampuan Penalaran Matematis dan Minat Belajar. Jurnal Riset Pendidikan Matematika, 4(1), 1-10. https://doi.org/10.21831/jrpm.v411.10066

Widodo, T., \& Kadarwati, S. (2013). High Order Thinking Berbasis Pemecahan Masalah Untuk Meningkatkan Hasil Belajar Berorientasi Pembentukan Karakter Siswa. Cakrawala Pendidikan, XXXII(1), 161-171.

Yamin, M. (2013). Strategi dan Metode dalam Model Model Pembelajaran. Jakarta: Press Group.

Yumiati., \& Noviyanti, M. (2017). Abilities of Reasoning and Mathematics Representation on Guided Inquiry Learning. Journal of Education and Learning, 11(3), 283-290. 